\title{
A Different Kind of Sharing Economy: A Literature Review of Platform Cooperatives
}

\author{
Jiang Zhu \\ University of Technology Sydney \\ Jiang.Zhu-2@student.uts.edu.au
}

\author{
Olivera Marjanovic \\ University of Technology Sydney \\ Olivera.Marjanovic@uts.edu.au
}

\begin{abstract}
We are now living in the so-called sharing economy, exemplified by the ride sharing platform Uber and short-term rental sharing platform Airbnb. In spite of the convenience and benefits of the sharing economy, there is a growing awareness of its negative and harmful societal effects. In response, platform cooperatives have started to emerge, aiming to create a different kind of sharing economy. However, the novelty of platform cooperatives combined with lack of research attention, continue to limit our understanding of the social and other benefits of platform cooperatives. The main objective of this paper is to provide a literature review on platform cooperatives, focusing on their social values and benefits. Analysis of the key publications reveals high potential of platform cooperatives as a more ethical and fairer alternative to platform capitalism that create value for their members/co-owners, while creating value for society.
\end{abstract}

\section{Introduction}

We are currently living in the so-called sharing economy, exemplified by the ride sharing (Uber) and the short term rental sharing (Airbnb) platforms. Although customers do enjoy an added convenience and other benefits of the sharing economy, its negative effects for individuals and the society have been heatedly raised and discussed in the scientific literature and popular press [1-4]. For instance, there is a continuing criticism of exploitation of digital labor in the ride sharing companies such as Uber, where precarious drivers are classified as independent contractors instead of employees, causing loss of the common employment benefits and protections $[2,5]$. Srnicek [1] popularized term "platform capitalism" to describe how big tech companies, enabled by digital platforms, are transforming global economy into a platform economy, while causing various societal problems, which are neglected in pursuit of profit.
As a result, a number of scholars and practitioners are calling for fairer and more ethical alternatives, while pointing to the notion of 'sharing', which is, according to many, misappropriated and misleading [6-8]. In response to the platform capitalism, platform cooperatives (aka platform co-ops) are rapidly emerging as a new direction in the sharing economy. Platform co-ops are in essence cooperatives, enabled by digital platforms, and as such have shared ownership and democratic control of the platform [8]. They emerged as a more ethical and fairer alternative to shareholder-owned monopolistic platform based companies [9-12]. According to the \#PlatformCoop Directory [13], there are currently over 300 platform co-ops and their support organizations globally.

However, the novelty and a limited research attention given to platform cooperatives continue to hinder our understanding of their social benefits and other types of value they create $[14,15]$. In response, this research aims to provide a literature review on platform cooperatives, centered on their social values and benefits. The review is based on a very limited number of research articles on platform co-ops, essential books and influential industry reports. Our analysis of the key publications reveals that they create a wide range of benefits for their members/co-owners combined with a positive social value.

Our literature review also confirms very limited research on platform cooperatives, with only a handful of papers published by multidisciplinary researchers. Besides, platform co-ops are yet to attract the attention of the Information Systems (IS) researchers. This is, in spite of IS' ongoing interest in the more traditional sharing economy, exemplified by platform capitalism. We therefore see our paper as trailblazing research on a new type of sharing economy in IS, and a novel research phenomenon that is platform co-ops.

We also hope that our research will inform and inspire other IS and multidisciplinary researchers to engage with this new digitally-enabled generation of the traditional cooperatives (coops), which are also 
neglected by the IS filed, compared to other types of business organizations.

The paper is organized as follows. Section 2 provides research background regarding platform cooperatives and platform cooperativism. Next the three-step literature review process is shown in section 3 , followed by discussions of major themes identified. Finally, future research implications and conclusion are presented in section 4 .

\section{Research Background}

Shareholder-owned platform companies, described by an umbrella term 'platform capitalism', are reported to cause a number of societal and environmental problems [2, 3, 11, 16, 17]. In response, Scholz and Schneider [8] popularized the term "platform cooperativism" and initiated an international platform cooperativism movement in 2014. Ever since, the movement has been growing, driven by joint efforts of platform co-op entrepreneurs and members, industry governing bodies of traditional coops, and an emerging group of international multidisciplinary researchers. Together, they continue to build, actively support and promote platform cooperatives as a more ethical and fairer alternative to platform capitalism.

Platform co-ops are in essence cooperatives organizations (co-ops), which are the oldest, yet stillrelevant and a growing type of human enterprises. Coops are people-centered enterprises, which are owned controlled and managed by, and for their members to realize their common economic, social and cultural needs and aspirations [18]. The widely-cited early example of modern co-ops, the Rochdale Equitable Pioneers Society, was established in 1844 in response to the economic and social distress caused by the emergence of mass production industrial techniques [11]. Co-ops could be for-profit or non-for-profit enterprises, each with strong commitment to creating social value. Consequently, they are also considered to be the earliest form of social enterprises.

Platform co-ops are the new type of co-ops, enabled by digital platforms and with business models based on the cooperative ownership structure [8]. Due to the cooperative member-based structure, platform co-ops distribute the value they generate on a more equitable basis, compared to shareholder-owned platform-based companies [2]. A key feature of platform co-ops is democratic control of the digital platform by its own members, who are also co-owners. Following the seven International Cooperatives Alliance (ICA) principles [18], which emphasize cooperatives values such as democratic member control, autonomy and independence, cooperation and concern for community, platform cooperatives are well positioned to contribute to a genuine sharing economy compared to the current 'sharing' economy.

Indeed, platform cooperatives are rapidly emerging in multiple industries such as ride sharing, short term rental sharing, online retailing and ondemand labor, just in the last few years. Just to name a few, there is Fairbnb as a member-owned alternative for Airbnb, Eva or Green Taxi Driver as an ethical, driver-co-owned alternative for Uber, and Fairmondo as an alternative for eBay.

According to Scholz [12], platform cooperativism is

“... about economics by other means. It is a nascent but growing political and economic movement that builds a fairer future of work by joining the values of the cooperative movement with internet technologies - apps, platforms, and protocols. Building on the successes of the free software movement, coop members, technologists, unionists, and freelancers create a concrete near-future alternative to the extractive sharing economy that is rooted in democratic ownership ", p.17.

Directly countering platform capitalism, Scholz [2] calls for platform cooperativism, which place people at the center of digital platform and turn profits into social and member benefits. This in turn, Scholz argues, could create and invigorate an authentic sharing economy by remedying the negative effects of platform capitalism and dignifying digital labor.

In recent years there is an increasing number of exploratory case studies of different specific platform co-ops, and platform co-operative reports [19-23]. Notable examples are musical platform Resonate, medical health data platform MIDATA, short term rental platform Fairbnb and photographers' platform Stocksy. However, research on platform co-ops remains scarce, making these new types of organizations 'invisible', or as Scholz [2] says 'hiding in the plain site', from the international research community. We aim to bring them to our collective attention through a literature review, conducted as follows.

\section{Literature Review}

The purpose of this literature review is to present an overview of the current research on platform co-ops and platform cooperativism, focusing on their social benefits and social values, in order to raise researchers' awareness of platform cooperatives. Our literature review process included the following three steps: planning, conducting and reporting the review. 


\subsection{Planning the review}

The overall research objective was to understand social benefits and social values of platform co-ops, with the platform coop being the main research phenomenon. We recognized that platform co-ops existed in a broader context of cooperatives organizations. Therefore, the topics of social impact or social value of cooperatives in general, and the role of IT/IS were also included in this literature review. Together these concepts were used to frame and scope our literature review, conducted as follows.

\subsection{Conducting the review}

\subsubsection{Search strategy}

The primary database used was Google Scholar, since it covered both peer-reviewed journals and conferences as well as reports and books. Because platform co-operatives are still an emerging research phenomenon [14, 15], our literature review also included the essential and widely cited books and industry reports on platform co-ops. Key words used included "platform cooperative*" OR "platform coop*" OR "cooperatives" to ensure a wide coverage of the multidisciplinary literature as possible on topics related to platform cooperatives and cooperatives in general. This initial search led to 1010 documents.

\subsubsection{Paper selection}

The objective of this step was to select relevant documents from the initial pool of 1010 documents.

Firstly, titles and abstracts of all 1010 documents were screened to exclude those documents that used term platform and cooperatives in other contexts unrelated to platform cooperatives. This exclusion criteria reduced the volume of relevant literature, which was in line with our expectation because of the limited research on platform co-ops $[14,15]$. Forward referencing search was also used on most cited platform cooperative literature to locate other relevant literature on platform cooperatives or platform cooperativism. Among them were the essential platform cooperative book 'Ours to Hack and to Own: The Rise of Platform Cooperativism' [8] and the widely-cited platform cooperativism report 'Platform cooperativism - Challenging the corporate sharing economy' by Scholz [2]. Repeated documents and non-English versions were also omitted. Through reading the abstracts and screening the full text if needed, those documents that simply mentioned platform cooperatives in several sentences or used platform cooperative examples in other contexts were also excluded from this literature review, leaving around 150 documents to be further examined.

The resulting pool of documents was then screened to eliminate investor-owned and other types of digital platforms that did not meet the criteria for platform cooperatives. Since our focus was on understanding social impact or value of platform cooperatives, we then focused on papers which included discussions on social impact and/or social value of cooperatives or platform cooperatives for different stakeholders, including communities and society. Further reading of the literature resulted in additional number of relevant that were discovered through backward reference search. This process resulted in the total of 42 highly relevant documents.

\subsubsection{Data Extraction}

Further details of those 42 papers are listed in Appendix 1, in chronological order, with information on the author(s), year published, title, reference type, journal name (if applicable) and key words. The reference type includes Book, Book (ed.), Book Chapter, Conference Paper, Journal Article, Report, Thesis and Web Page.

\subsection{Reporting the review}

\subsubsection{Exploration and overview of documents}

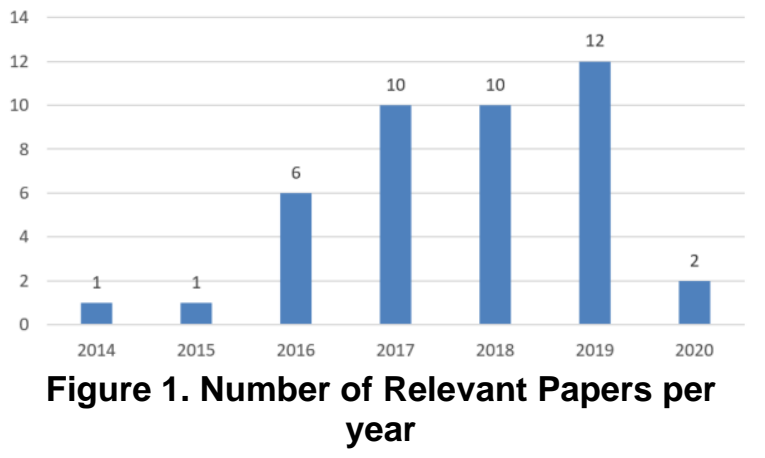

As it can be seen from Appendix 1 and Figure 1, all relevant documents were published from year 2014 to the first half of year 2020, with a number of publications growing in years 2017, 2018 and 2019. This was very much expected, since platform based companies and especially platform co-ops have been rapidly emerging in recent years [11, 15, 24, 25]. Various negative social effects and societal problems associated with so-called sharing economy, have prompted an increased, yet still limited interest in studying platform co-ops among researchers $[2,9,10$, 17, 26].

Considering the types of those 42 documents identified, there are 25 scholarly documents including 
16 journal articles, 5 conference papers plus 3 theses. The remaining 17 documents are made up of 7 books and book chapters (including an edited book) and 8 reports. It is also interesting to note that these documents came from different disciplines, including business, information technology, information systems, sociology and sustainability sciences, which establishes platform co-operative as a multidisciplinary socio-technical research phenomenon.

It is worth noting that 10 documents included case studies or at least descriptions of different platform cooperative, which again suggests the explorative stage of research on platform co-operatives [27].

Finally, based on the keywords used to describe research on platform co-ops and platform cooperativism, researchers focused on business models, traditional cooperatives, digital labor, discrimination, platform capitalism, surveillance capitalism, sharing economy, social entrepreneurship and sustainability. Research studies either related to negative social effects of current platform based companies or implied positive social benefits from platform cooperatives.

\subsubsection{Thematic exploration of documents}

While reading and reviewing the resulting pool of 42 documents, common themes or dimensions were identified and used to group related papers together. In this way, six major themes were identified and recorded in Table 1, with relevant references under each theme. The table is not exhaustive as some papers could be classified under more than one themes, due to the content they cover. In that case the most prominent theme was used.

Table 1. Common themes of papers reviewed

\begin{tabular}{|l|l|}
\hline \multicolumn{1}{|c|}{ Themes } & \multicolumn{1}{c|}{ Relevant Paper } \\
\hline $\begin{array}{l}\text { 1. Social } \\
\text { impact or } \\
\text { social value of } \\
\text { cooperatives } \\
\text { or cooperative } \\
\text { principles }\end{array}$ & $\begin{array}{l}\text { (Scholz, 2016); (Graham and } \\
\text { (Ridley-Duff, Wren and }\end{array}$ \\
\hline $\begin{array}{l}\text { Yazici, 2018); (Stocker and } \\
\text { Takara, 2019) }\end{array}$ \\
$\begin{array}{l}\text { Timpact of } \\
\text { digital } \\
\text { platform } \\
\text { technology }\end{array}$ & $\begin{array}{l}\text { (Kewell, Adams and Parry, 2017); } \\
\text { (Graham, Hjorth and Lehdonvirta, }\end{array}$ \\
\hline
\end{tabular}

\begin{tabular}{|c|c|}
\hline $\begin{array}{l}\text { 3. Negative } \\
\text { social effects } \\
\text { associated } \\
\text { with extractive } \\
\text { platform based } \\
\text { companies or } \\
\text { platform } \\
\text { capitalism }\end{array}$ & $\begin{array}{l}\text { (Edelman and Luca, 2014); } \\
\text { (Zuboff, 2015); (Srnicek, 2016); } \\
\text { (Barzilay and Ben-David, 2016); } \\
\text { (Scholz, 2016); (Ge, Knittel, } \\
\text { MacKenzie and Zoepf, 2016); } \\
\text { (Graham, Hjorth and Lehdonvirta, } \\
\text { 2017); (Tytko, 2017); (Frenken, } \\
\text { van Waes, Smink and van Est, } \\
\text { 2017); (Van Doorn, 2017); } \\
\text { (Bajwa, Gastaldo, Di Ruggiero } \\
\text { and Knorr, 2018); (Chee, 2018); } \\
\text { (Ganapati and Reddick, 2018); } \\
\text { (Landwehr, Borning and Wulf, } \\
\text { 2019); (Borkin, 2019) }\end{array}$ \\
\hline $\begin{array}{l}\text { 4. Positive } \\
\text { social benefits } \\
\text { associated } \\
\text { with platform } \\
\text { cooperatives } \\
\text { or platform } \\
\text { cooperativism }\end{array}$ & $\begin{array}{l}\text { (Scholz, 2016); (Graham and } \\
\text { Shaw, 2017); (Fuster and Espelt, } \\
\text { 2017); (Zygmuntowski, 2018); } \\
\text { (Schneider, 2018); (Scholz, 2018); } \\
\text { (Scholz, 2018b); (Burnicka and } \\
\text { Zygmuntowski, 2019); (Saner, Yiu } \\
\text { and Nguyen, 2019); (Foramitti, } \\
\text { Varvarousis and Kallis, 2020) }\end{array}$ \\
\hline $\begin{array}{l}\text { 5. Challenges } \\
\text { facing } \\
\text { platform } \\
\text { cooperatives } \\
\text { or platform } \\
\text { cooperativism }\end{array}$ & $\begin{array}{l}\text { (Scholz, 2016); (Van Doorn, } \\
\text { 2017); (McCann and Yazici, } \\
\text { 2018); (Scholz, 2018); (Ridley- } \\
\text { Duff, Wren and McCulloch, } \\
\text { 2018); (Borkin, 2019); (Sandoval, } \\
\text { 2019) }\end{array}$ \\
\hline $\begin{array}{l}\text { 6. Early case } \\
\text { studies of } \\
\text { platform } \\
\text { cooperatives }\end{array}$ & $\begin{array}{l}\text { (Schumilas, n.d.); (Fuster and } \\
\text { Espelt, 2017); (Pazaitis, Kostakis } \\
\text { and Bauwens, 2017); (Conaty, } \\
\text { Bird and Ross, 2018); (Ridley- } \\
\text { Duff, Wren and McCulloch, } \\
\text { 2018); (Mòdol, 2019); (Saner, Yiu } \\
\text { and Nguyen, 2019); (Foramitti, } \\
\text { Varvarousis and Kallis, 2020); } \\
\text { (Grayer, 2020) }\end{array}$ \\
\hline
\end{tabular}

Theme 1- Social impact or social value of cooperatives or cooperative principles and Theme 2Social impact of digital platform technology are the key two themes considered by the researchers in relation to the social impact or social value of platform cooperatives. Documents grouped in Theme 1 showed the social value related to employing a cooperative business model and following the seven cooperative principles, such as fair distribution of value, democracy and transparency [2, 28, 29]. While Theme 2 covered innovative platform technologies including the use of block chain, tailored mobile apps and sophisticated embedded algorithms. Although innovative, technology alone was not considered to be a solution to social problems, as it is often the case 
with the technological solutionism approach of platform capitalism [2].

Theme 3- Negative social effects associated with extractive platform based companies or platform capitalism and Theme 4- Positive social benefits associated with platform cooperatives or platform cooperativism are closely related, as documents grouped here point out to different negative social effects or social problems under platform capitalism and therefore calling for ethical and fairer alternatives. Platform cooperatives are responding to this call by offering some solutions to those negative societal effects, and in turn creating social benefits $[2,9-12,17$, 26, 30].

Theme 5 focuses on challenges facing platform cooperatives or platform cooperativism. Documents grouped here discuss a number of emerging challenges faced by platform co-ops, including access to capital, competing with incumbent big tech companies, concern over governance and scalability issues $[2,9$, 10, 29, 31].

Finally Theme 6 groups documents that conducted case studies of specific platform cooperatives in an explorative manner. These case studies provide empirical evidence of various positive effects of platform cooperatives in different industries such as ride sharing (Green Taxi Cooperative), music entertainment (resonate), medical health (MIDADA), online labor brokerage (Loconomics), short term rental sharing (Fairbnb) and arts (Stocksy). These case studies contribute to an initial understanding of different type of platform cooperatives and the associated social and other types of values.

\subsection{Discussion on identified themes}

\subsubsection{Social value of cooperatives or cooperative principles}

By definition, cooperatives exist to meet both social and cultural needs of their members and a wider society, in addition to meeting the economic needs of their members [32]. By bringing people together to cocreate something that satisfies their collective interests and needs, platform co-ops are also expected to create and accumulate social wealth [33].

Here we adopted Emerson's [34] definition of social value, which "... is created when resources, inputs, processes or policies are combined to generate improvements in the lives of individuals or society as $a$ whole". There are also social values implied in the seven cooperative principles, which were initially developed by those Rochdale pioneers. An updated version of cooperative principles by ICA contains following principles [35]: 1. Voluntary and open membership, 2. Democratic member control, 3. Member economic participation, 4. Autonomy and independence, 5. Education, training and information, 6. Co-operation among cooperatives and 7. Concern for community. These principles guide cooperatives to put their common values such as democracy, equality and solidarity into practice [18]. Cooperative members also believe in ethical values such as openness, social responsibility and caring for others.

Platform co-ops, formed around these cooperative principles, are also using digital platforms to practice openness, cooperation and democracy as well as lifelong learning and sustainable development for their community.

Based on ICA principles, Scholz [2] proposed 10 platform cooperativism principles, focusing on the digital platform and digital labor as their distinct characteristics. They are depicted by Figure 2 .

1. Collective member based ownership

2. Decent pay and income security

3. Transparency and data portability

4. Appreciation and acknowledgment

5. Co-determined work involving workers 6. A protective legal framework

7. Portable worker protections and benefits

8. Protection against arbitrary behaviour

9. Rejection of excessive workplace surveillance 10. The right to $\log$ off

Figure 2. The 10 Platform cooperativism Principles [2]

As it can be seen from the above principles, most of them are concerned with improvement of worker conditions and lives of people using these digital platforms. The adoption of worker cooperative structure, which aims to improve worker conditions, dignify human work and grant worker members democratic control [36], is a direct response to the current exploitative practices of 'platform capitalism' [28]. Following the cooperative principles, especially those related to providing education and training opportunities, platform co-op's workers are expected to benefit from upskilling, and the resulting career development opportunities, which in turn is expected to lead to their improved living standard [17]. For example, based on a survey of the riders and driver users of ride sharing digital platform co-ops, Stocker and Takara [11] found that by fostering a sense of community and ownership through cooperative model, platform cooperatives could enjoy a competitive advantage over their platform capitalist counterparts. 


\subsubsection{Social impact of digital platform technology}

Currently digital platform technology plays an import role in boosting platform connectivity for matchmaking and mediating social interactions [10, $24,37]$. At the same time, technology is a doubleedged sword that could have both positive and negative effects, which ultimately depends on the main purpose of using digital platform technology. For instance, digital platforms in general have the potential to either increase or reduce gender or racial discrimination by controlling how and when user profiles are revealed, i.e. by masking or unmasking the characteristic that could contribute to discrimination $[37,38]$.

There is currently a large body of research focused on negative social effects caused by digital platform technology used by the extractive big tech platform based companies. The reported examples of harmful effects include increased surveillance capitalism invading privacy, behavior manipulation through algorithms, added discrimination against gender or race, price discrimination that erodes consumer surplus and negative impact on wider communities $[24,39,40]$. Moreover, the opaqueness of the algorithms employed by capitalist platforms and discretion to modify these algorithms to enable platform owners to extract maximum value from platform users (both workers and customers) also contribute to serious social harm [17, 40].

However, if used ethically, digital platform technology has lots of potential in bringing positive social impact such as adding more transparency, reducing gender or racial discrimination, creating jobs beyond locale limit, boosting economic development while reducing poverty and creating sustainable environments [37, 38, 41, 42]. Indeed, as Frenken, et al. [24] suggested, platform cooperatives can make good use of ICTs to scale up and counter the ICT practices of for-profit platforms, while benefiting from the same technology.

Moreover, digital platform technology could lift up the cooperative model and enable platform co-ops to operate in new ways and at scale [9]. By incorporating the cooperative principles into the design of the coowned digital platform, platform co-ops are therefore well-positioned to create positive social impact and realize those expected social values $[17,21,25]$.

Other technological innovations used by platform co-ops such as those powered by Big Data, as shown by Tortora et al. [43], could lead to new value propositions, such as those resulting from the codesign of a sustainable tourism experience. Additionally, innovative blockchain technology, already used by platform co-ops, could be further leveraged to deliver socially and environmentally beneficial outcomes, by transforming the existing business models and offering new value creation opportunities [44]. Therefore, reflecting on Theme 1 and Theme 2, by combining cooperative principles and innovative digital platform technology, platform co-ops are much better positioned to create positive social effects compared to their platform capitalism counterparts.

\subsubsection{Negative social effects associated with platform capitalism}

It is suggested by a number of scholars that the existing sharing economy is creating huge controversy and causing social and environmental problems $[2,3$, $16,24,30,45]$. The most cited negative social effects include the exploitation of digital labor and worsening worker conditions $[2,9,12,16,19,21,37,46]$. Scholz [2] pointed out that in the platform capitalism workers are regarded as independent contractors, rather than employees. Consequently, they suffer from loss of wider social benefits such as worker insurance, collective bargaining power and worker protections [2, 19, 42, 46]. Scholz [2] summarized worsening worker conditions into five categories, such as stagnating wages, stalled rights as independent contractors, lack of digital workplace democracy, invisible labor without acknowledgement (especially in cleaning industry) and shifted risks onto workers. In spite of the precarity of digital labor and worsening worker conditions, there is still a fierce competition among digital platform workers, due to imbalance of supply and demand of digital labor. This in turn forces many workers to engage in underbidding practices, which only increase their precarity [37]. As Graham and Wood [28] suggested, these platform based companies by design treat labor work as commodities that can be bought and sold. The design and control of the platform also makes distributed workers feel lonely and socially isolated while doing tedious work, which in turn creates certain mental health risks such as anxiety and depression [37, 40, 46].

Apart from worsening worker conditions, platform capitalist companies also tend to facilitate surveillance capitalism that monetizes users' personal data and everyday interaction data, raising concern on privacy and ownership of data $[1,12,24,39,40]$. As Landwehr, Borning and Wulf [40] pointed out, surveillance capitalism has various negative effects on society such as threatened democracy, fueled social fragmentation and increased environmental concern.

Inequalities and discrimination in terms of income, gender and race are also present or exacerbated within the extractive platform based companies [12, 47, 48]. The extractive nature of their business models 
whereby workers' resources are used to generate (i.e. 'extract') profit for few shareholders, resulted in unfair distribution and concentration of wealth leading to increasing income inequalities [11, 20, 24, 37]. Digital discrimination against certain race and gender are also present in platform capitalism, notably in ride sharing platforms and short term rental sharing platforms [5, $25,38,47]$. Ge et al. [48] found a pattern of racial and gender discrimination present in ride sharing platform companies such as Uber and Lyft. Barzilay and BenDavid [38] termed "Discrimination 3.0" as the third generation of gender inequality and showed its existence in digital labor work, in the form of a huge gender gap in the hourly rate.

There are also legal concerns around those platform based companies [5, 26]. For instance, Slee [4] observed that previously protected or personal areas of our lives are now touched by a harsh and deregulated free market under the disguise of sharing economy. Tytko [26] also argued that due to the confusion of the blurred definition or terms associated with the sharing economy trend, there is an increased legal gray area around accelerated precarity.

Consequently, some countries have banned platform capitalist companies. For example, Uber has been fully or partially banned by a number of countries (such as Denmark, France and Spain) and may face future bans in other countries. Similar to Uber, Airbnb is banned in a number of cities or countries (such as Japan, Barcelona of Spain).

\subsubsection{Positive social benefits associated with platform cooperatives or platform cooperativism}

In response to those negative societal effects of extractive platform companies, platform co-ops are set to bring positive social and environment benefits $[2,9$ $11,17,22,23,26]$. Some of the reported social benefits and values include democracy, transparency, fairness, sustainability, equitable value distribution and environmentally beneficial outcomes $[12,17,20$, 37].

Platform co-ops also provide better worker conditions in terms of worker protections, benefits, fair decent pay, job security and support from union [12, 19, 21, 28, 41]. Worker-owned platform co-ops are thus seen as an ethical solution which prevents exploitation of digital labor [6, 25]. Saner, Yiu and Nguyen [21] suggested that democratic governance of platform co-ops also ensures higher workers' satisfactions. Grayer [23] used the case of platform coop Stocksy to argue that the cooperative model offers precarious workers a sense of community, autonomy and fairness.
Countering surveillance capitalism and data ownership problem under current sharing economy, platform cooperatives give back ownership and control of data to their members and users [2, 6, 49]. Scholz [2] and Mòdol [20] used the example of health data coop MIDATA to illustrate that by giving users full control over their health-related data, they could decide to make their data available to medical researchers as a social common good. Additionally, any incomes generated from MIDATA data is reinvested into research projects for the social benefits of all, not just its members [20].

Platform cooperatives also promote and enhance equality by distributing the resulting values at more equitable and fairer basis [11, 12, 14, 20, 29]. The cooperative business model is considered to return much higher proportions of profits made to workers, instead of concentrating wealth in the hands of few platform owners or shareholders $[6,10]$.

By incorporating platform cooperativism principles into platform design, platform co-ops are also better positioned to counter racial, gender and other forms of discrimination compared to the extractive platform companies [25]. McCann and Yazici [10] described the cleaners' platform co-op Si Se Puede (We Can Do It), which gives all their members, who are all migrant women, equal say over their business decisions.

Another social value implied in platform co-ops literature is their connection with sustainability and sustainable development [15, 29, 41, 50-53]. For example, Roelants, Hyungsik and Terrasi [54] showed evidence of positive sustainability effects of social economy, including platform co-ops.

When used by platform cooperatives, innovative digital technology such as blockchain could be used for public good and even fulfil the United Nations Sustainable Development Goals [44]. Community cryptocurrency such as FairCoin used by platform coop FairCoop could be used as a tool to enable sustainable and prosperous economic development [52].

\section{Conclusions, Limitations and Future Work}

In conclusion, this literature review confirms that platform co-ops are reported to be a fairer and more ethical alternative to better-known extractive platform capitalist companies. Enabled by digital platform technology and based on a collective ownership and the democratic cooperative business model, platform cooperatives are already creating a different kind of sharing economy exemplified by various economic, social and environmental benefits. 
Our research also confirms that the nascent literature on platform co-ops is still very much influenced by the existing literature on the mainstream sharing economy, and focused on comparing platform co-ops to their better-known counterparts. We perceive the need for future research which is entirely focused on platform co-ops, without any need for comparison and justification of their existence as an alternative. We also argue that any future research on platform co-ops should consider a very long history of more traditional cooperatives and the rich body of literature in this domain.

Our literature review is limited to the documents discovered through Google Scholar. We acknowledge that further search of scholarly databases may result in more journal and conference papers, not included in our current pool of 150 publications.

Our current and future work includes empirical case studies of platform cooperatives, focusing on their value creation mechanisms. We hope that this literature review will inspire other multidisciplinary researchers to consider platform cooperatives. This paper is our call for action and an invitation to join forces and collaborate.

\section{References}

[1] Srnicek, N., Platform capitalism. 2016: John Wiley \& Sons.

[2] Scholz, T., Platform cooperativism: Challenging the corporate sharing economy. 2016: New York.

[3] Schor, J.B. and W. Attwood - Charles, The "sharing" economy: labor, inequality, and social connection on for-profit platforms. Sociology Compass, 2017. 11(8): p. e12493.

[4] Slee, T., What's yours is mine: Against the sharing economy. 2017: Or Books.

[5] van Doorn, N., Platform labor: on the gendered and racialized exploitation of low-income service work in the 'on-demand' economy. Information, Communication \& Society, 2017. 20(6): p. 898914.

[6] Frenken, K., Political economies and environmental futures for the sharing economy. Philosophical Transactions of the Royal Society A: Mathematical, Physical and Engineering Sciences, 2017. 375(2095): p. 20160367.

[7] Graham and M.A. Anwar, Two models for a fairer sharing economy. The Cambridge Handbook of the Law of the Sharing Economy. 2018, Cambridge: Cambridge University Press. 328340.

[8] Scholz, T. and N. Schneider, Ours To Hack and Own: The Rise of Platform Cooperatives. 2016, New York/London: OR Books.

[9] Borkin, S., Platform co-operatives-solving the capital conundrum. 2019, Nesta \& Co-operatives UK, luty.
[10] McCann, D. and E. Yazici, Disrupting Together: The Challenge (and Opportunities). 2018.

[11] Stocker, A. and M. Takara, Evaluating the Potential of Cooperative Ridesourcing: A Case Study of Arcade City in Austin, Texas. 2019, Sustainable Economies Law Center.

[12] Scholz, T., How To Coop The Digital Economhy, in MONEYL B. 2018. p. 197.

[13] PlatformCoop Directory. n.d. [cited 2020; Available from: https://ioo.coop/directory/.

[14] Puranen, R., Owning the Sharing Economy-Comparing the business models between platform cooperatives and investor owned sharing economy platforms. 2019.

[15] Fuster, M. and R. Espelt, Platform Cooperativism Holistic Characterization and Delimitation: 10 Cases of Barcelona Ecosystem. Re-embedding the Social: Cooperatives, Political Consumerism and Alternative Lifestyles. SASE, 2017.

[16] Chee, F.M., An Uber ethical dilemma: examining the social issues at stake. Journal of Information, Communication and Ethics in Society, 2018.

[17] Zygmuntowski, J., Commoning in the Digital Era: Platform Cooperativism as a Counter to Cognitive Capitalism. Praktyka teoretyczna, 2018(27): p. 168-192.

[18] ICA. n.d.; Available from: https://www.ica.coop/en/cooperatives/cooperative-identity.

[19] Conaty, P., A. Bird, and C. Ross, Working together: Trade union and co-operative innovations for precarious workers. 2018, Co-operatives UK: Manchester.

[20] Mòdol, J.R., Citizens' Cooperation in the Reuse of Their Personal Data: The Case of Data Cooperatives in Healthcare, in Collaboration in the Digital Age: How Technology Enables Individuals, Teams and Businesses. 2019. p. 159.

[21] Saner, R., L. Yiu, and M. Nguyen. Platform Cooperatives: The Social and Solidarity Economy and the Future of Work. in Presented at UNTFSSE International Conference in Geneva. 2019.

[22] Foramitti, J., A. Varvarousis, and G. Kallis, Transition within a transition: how cooperative platforms want to change the sharing economy. Sustainability Science, 2020: p. 1-13.

[23] Grayer, S., Stocksy United: A case study of co-operation in the cultural industries. 2020, Communication, Art \& Technology: School of Communication.

[24] Frenken, K., et al., A fair share: Safeguarding public interests in the sharing and gig economy. 2017, Rathenau Instituut.

[25] Schneider, N., An Internet of ownership: Democratic design for the online economy. The Sociological Review, 2018. 66(2): p. 320-340.

[26] Tytko, K., Is sharing truly caring? The capitalisation of fthe sharing economy. 2017.

[27] Yin, R.K., Case study research and applications: Design and methods. 2017: Sage publications.

[28] Graham and A. Wood. Why the digital gig economy needs co-ops and unions. 2016 [cited 2020; Available from: 
https://www.opendemocracy.net/en/opendemocra cyuk/why-digital-gig-economy-needs-co-opsand-unions/.

[29] Ridley-Duff, R., D. Wren, and M. McCulloch, Wealth, Social Enterprise and the FairShares Model. Journal of Human Welfare Studies, 2018.

[30] Graham and J. Shaw, Towards a fairer gig economy. 2017: Meatspace Press.

[31] Sandoval, M., Entrepreneurial Activism? Platform Cooperativism Between Subversion and Cooptation. Critical Sociology, 2019: p. 0896920519870577.

[32] Birchall, J., A member-owned business approach to the classification of co-operatives and mutuals. The Co-operative Model in Practice, 2012: p. 67.

[33] Novkovic, S. and T. Webb, Co-operatives in a PostGrowth Era: Creating co-operative economics. 2014: Zed Books.

[34] Emerson, J., J. Wachowicz, and S. Chun, Social Return on Investment (SROI): Exploring aspects of value creation. Harvard Business School, Working Knowledge for Business Leaders. Acedido em, 2001.

[35] Co-operative Principles. n.d. [cited 2020; Available from: https://www.co-op.ac.uk/about/valuesandprinciples.

[36] CICOPA/ICA. World declaration on worker cooperatives. 2005.

[37] Graham, I. Hjorth, and V. Lehdonvirta, Digital labour and development: impacts of global digital labour platforms and the gig economy on worker livelihoods. Transfer: European Review of Labour and Research, 2017. 23(2): p. 135-162.

[38] Barzilay, A.R. and A. Ben-David, Platform inequality: gender in the gig-economy. Seton Hall L. Rev., 2016. 47: p. 393.

[39] Zuboff, S., Big other: surveillance capitalism and the prospects of an information civilization. Journal of Information Technology, 2015. 30(1): p. 75-89.

[40] Landwehr, M., A. Borning, and V. Wulf. The High Cost of Free Services: Problems with Surveillance Capitalism and Possible Alternatives for IT Infrastructure. in Proceedings of the Fifth Workshop on Computing within Limits. 2019.

[41] Burnicka, A. and J.J. Zygmuntowski, Platform Cooperativism as the Engine of Solidary Growth. 2019.

[42] Ganapati, S. and C.G. Reddick, Prospects and challenges of sharing economy for the public sector. Government Information Quarterly, 2018. 35(1): p. 77-87.
[43] Tortora, D., et al. Using Big Data to co-design a sustainable tourist experience. Some highlights by means of a practical example. in Sinergie-Sima Management Conference:" Management and sustainability: Creating shared value in the digital era". 2019. IT.

[44] Kewell, B., R. Adams, and G. Parry, Blockchain for good? Strategic Change, 2017. 26(5): p. 429-437.

[45] Codagnone, C. and B. Martens, Scoping the sharing economy: Origins, definitions, impact and regulatory issues. Cristiano Codagnone and Bertin Martens (2016). Scoping the Sharing Economy: Origins, Definitions, Impact and Regulatory Issues. Institute for Prospective Technological Studies Digital Economy Working Paper, 2016. 1.

[46] Bajwa, U., et al., The health of workers in the global gig economy. Globalization and health, 2018. 14(1): p. 1-4.

[47] Edelman, B.G. and M. Luca, Digital discrimination: The case of Airbnb. com. Harvard Business School NOM Unit Working Paper, 2014(14-054).

[48] Ge, Y., et al., Racial and gender discrimination in transportation network companies. 2016, National Bureau of Economic Research.

[49] Schneider, N., Owning is the new sharing. Shareable, 2014. 21: p. 2014.

[50] Morell, M.F. and R. Espelt, A Framework to Assess the Sustainability and the Pro-Democratization of Platform Economy. 2019.

[51] Bates, O. and B. Kirman, Sustainable Platform Cooperativism: Towards social and environmental justicce in the future of the gigeconomy. Limits 2019, 2019.

[52] Kasliwal, P., Community Cryptocurrencies for Sustainable Prosperity: A case study of FairCoin. 2019.

[53] Gossen, M., J. Pentzien, and J. Peuckert. What use is it really for sustainability? Potentials and impacts of peer-to-peer sharing in the domains of accommodation and mobility. in NachhaltigkeitsManagementForum| Sustainability Management Forum. 2019. Springer.

[54] Roelants, B., E. Hyungsik, and E. Terrasi, Cooperatives and employment: A global report. Quebec: CICOPA/Desjardin, 2014. 


\section{Appendix List of Literature Review Included}

\begin{tabular}{|c|c|c|c|c|}
\hline (Author, Year) & Name & Type & Journal & Key Words \\
\hline (Edelman and Luca, 2014) & Digital Discrimination: The Case of Airbnb.com & Journal Article & Harvard Business Review & Discrimination \\
\hline (Zuboff, 2015) & $\begin{array}{l}\text { Big other: surveillance capitalism and the prospects } \\
\text { of an information civilization }\end{array}$ & Journal Article & Journal of Information Technology & Surveillance Capitalism \\
\hline (Barzilay and Ben-David, 2016) & Platform inequality: gender in the gig-economy & Journal Article & Seton Hall Law Review & Discrimination \\
\hline (Ge, Knittel, MacKenzie and Zoepf, 2016) & $\begin{array}{l}\text { Racial and gender discrimination in transportation } \\
\text { network companies }\end{array}$ & Report & NA & Discrimination \\
\hline (Graham and Wood, 2016) & $\begin{array}{l}\text { Why the digital gig economy needs co-ops and } \\
\text { unions }\end{array}$ & Web Page & NA & Platform Cooperatives \\
\hline (Scholz and Schneider, 2016) & Ours To Hack and To Own & Book(ed.) & NA & $\begin{array}{l}\text { Platform Cooperativism, Digital } \\
\text { Labour }\end{array}$ \\
\hline (Scholz, 2016) & $\begin{array}{l}\text { Platform Cooperativism - Challenging the Corporate } \\
\text { Sharing Economy }\end{array}$ & Report & NA & Platform Cooperativism \\
\hline (Srnicek, 2016) & Platform Capitalism & Book & NA & Platform Capitalism \\
\hline (Frenken, 2017) & $\begin{array}{l}\text { Political economies and environmental futures for } \\
\text { the sharing economy }\end{array}$ & Journal Article & $\begin{array}{l}\text { Philosophicla Transactions of the } \\
\text { Royal Society A }\end{array}$ & Sharing Economy \\
\hline (Frenken, van Waes, Smink and van Est, 2017) & $\begin{array}{l}\text { A fair share: Safeguarding public interests in the } \\
\text { sharing and gig economy }\end{array}$ & Report & NA & Sharing Economy \\
\hline (Fuster and Espelt, 2017) & $\begin{array}{l}\text { Platform Cooperativism Holistic Characterization } \\
\text { and Delimitation: } 10 \text { Cases of Barcelona Ecosystem }\end{array}$ & Conference Paper & NA & $\begin{array}{l}\text { Platform Cooperativism, } \\
\text { Sustainability }\end{array}$ \\
\hline (Graham and Shaw, 2017) & Towards a fairer gig economy & Book(ed.) & NA & Platform Cooperatives \\
\hline (Graham, Hjorth and Lehdonvirta, 2017) & $\begin{array}{l}\text { Digital labour and development: impacts of global } \\
\text { digital labour platforms and the gig economy on } \\
\text { worker livelihoods }\end{array}$ & Journal Article & $\begin{array}{l}\text { Transfer: European Review of } \\
\text { Labour and Research }\end{array}$ & Digital Labour \\
\hline (Kewell, Adams and Parry, 2017) & Blockchain for good? & Journal Article & Strategic Change & $\begin{array}{l}\text { Sustainable Development Goals, } \\
\text { Blockchain }\end{array}$ \\
\hline (Pazaitis, Kostakis and Bauwens, 2017) & $\begin{array}{l}\text { Digital economy and the rise of open cooperativism: } \\
\text { the case of the Enspiral Network }\end{array}$ & Journal Article & $\begin{array}{l}\text { Transfer: European Review of } \\
\text { Labour and Research }\end{array}$ & $\begin{array}{l}\text { Platform Cooperativism, Social } \\
\text { Entrepreneurship }\end{array}$ \\
\hline (Scholz, 2017) & $\begin{array}{l}\text { Uberworked and Underpaid: How Workers Are } \\
\text { Disrupting the Digital Economy }\end{array}$ & Book & NA & $\begin{array}{l}\text { Platform Cooperativism, Digital } \\
\text { Labour }\end{array}$ \\
\hline (Tytko, 2017) & $\begin{array}{l}\text { Is sharing truly caring? The capitalisation of the } \\
\text { sharing economy }\end{array}$ & Thesis & NA & Platform Capitalism \\
\hline (Van Doorn, 2017) & $\begin{array}{l}\text { Platform labor: on the gendered and racialized } \\
\text { exploitation of low-income service work in the } \\
\text { 'ondemand' economy }\end{array}$ & Journal Article & $\begin{array}{l}\text { Information, Communication \& } \\
\text { Society }\end{array}$ & Discrimination, Digital Labour \\
\hline (Bajwa, Gastaldo, Di Ruggiero and Knorr, 2018) & The health of workers in the global gig economy & Journal Article & Globalization and Health & Digital Labour \\
\hline 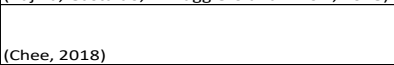 & $\begin{array}{l}\text { An Uber ethical dilemma: examining the social } \\
\text { issues at stake }\end{array}$ & Journal Article & $\begin{array}{l}\text { Journal of Information, } \\
\text { Communication and Ethics in } \\
\text { Society }\end{array}$ & Ethics, Digital Labour \\
\hline (Conaty, Bird and Ross, 2018) & $\begin{array}{l}\text { Working together - Trade union and co-operative } \\
\text { innovations for precarious workers }\end{array}$ & Report & NA & Cooperatives, Digital Labour \\
\hline (Ganapati and Reddick, 2018) & $\begin{array}{l}\text { Prospects and challenges of sharing economy for } \\
\text { the public sector }\end{array}$ & Journal Article & Government Information Quarterly & Sharing Economy \\
\hline (McCann and Yazici, 2018) & $\begin{array}{l}\text { Disrupting Together The Challenges (and } \\
\text { Opportunities) for Platform Co-Operatives }\end{array}$ & Report & NA & Platform Cooperatives \\
\hline (Ridley-Duff, Wren and McCulloch, 2018) & Wealth, Social Enterprise and the FairShares Model & Journal Article (Submitted) & $\begin{array}{l}\text { Journal of Human Welfare Studies } \\
\text { (Submitted) }\end{array}$ & $\begin{array}{l}\text { Sustainable Development Goals, } \\
\text { Platform Cooperatives }\end{array}$ \\
\hline (Schneider, 2018) & $\begin{array}{l}\text { An Internet of ownership: Democratic design for the } \\
\text { online economy }\end{array}$ & Journal Article & The Sociological Review & Platform Cooperativism \\
\hline (Scholz, 2018) & How to Coop the Digital Economy & Book Chapter & NA & Platform Cooperativism \\
\hline (Scholz, 2018b) & $\begin{array}{l}\text { Own This! A Portfolio of Platform Cooperativism, in } \\
\text { Progress }\end{array}$ & Web Page & NA & Platform Cooperativism \\
\hline (Zygmuntowski, 2018) & $\begin{array}{l}\text { Commoning in the Digital Era: Platform } \\
\text { Cooperativism as a Counter to Cognitive Capitalism }\end{array}$ & Journal Article & Praktyka teoretyczna & Platform Cooperativism \\
\hline (Bates and Kirman, 2019) & $\begin{array}{l}\text { Sustainable Platform Cooperativism - Towards social } \\
\text { and environmental justice in the future of the gig- } \\
\text { economy }\end{array}$ & Working Paper & NA & $\begin{array}{l}\text { Platform Cooperativism, } \\
\text { Sustainability }\end{array}$ \\
\hline (Borkin, 2019) & $\begin{array}{l}\text { Platform co-operatives - solving the capital } \\
\text { conundrum }\end{array}$ & Report & NA & Platform Cooperatives \\
\hline (Burnicka and Zygmuntowski, 2019) & $\begin{array}{l}\text { \#CoopTech: Platform Cooperativism as the Engine of } \\
\text { Solidary Growth }\end{array}$ & Report & NA & Platfrom Cooperatives \\
\hline (Landwehr, Borning and Wulf, 2019) & $\begin{array}{l}\text { The High Cost of Free Services: Problems with } \\
\text { Surveillance Capitalism and Possible Alternatives for } \\
\text { IT Infrastructure }\end{array}$ & Conference Paper & NA & $\begin{array}{l}\text { Surveillance Capitalism, Digital } \\
\text { Labour }\end{array}$ \\
\hline (Mòdol, 2019) & $\begin{array}{l}\text { Citizens' Cooperation in the Reuse of Their Personal } \\
\text { Data: The Case of Data Cooperatives in Healthcare }\end{array}$ & Book Chapter & NA & $\begin{array}{l}\text { Platform Cooperatives, Data } \\
\text { Cooperatives }\end{array}$ \\
\hline (Morell and Espelt, 2019) & $\begin{array}{l}\text { A Framework to Assess the Sustainability and the } \\
\text { Pro-Democratization of Platform Economy }\end{array}$ & Conference Paper & NA & $\begin{array}{l}\text { Platform Cooperativism, } \\
\text { Sustainability }\end{array}$ \\
\hline (Puranen, 2019) & $\begin{array}{l}\text { Owning the Sharing Economy - Comparing the } \\
\text { business models of platform cooperatives and } \\
\text { investor owned sharing economy platforms }\end{array}$ & Thesis & NA & $\begin{array}{l}\text { Platform Cooperatives, Business } \\
\text { Models }\end{array}$ \\
\hline (Sandoval, 2019) & $\begin{array}{l}\text { Entrepreneurial Activism? Platform Cooperativism } \\
\text { Between Subversion and Co-optation }\end{array}$ & Journal Article & Critical Sociology & Platform Cooperativism \\
\hline (Saner, Yiu and Nguyen, 2019) & $\begin{array}{l}\text { Platform Cooperatives: The Social an Solidarity } \\
\text { Economy and the Future of Work (A Preliminary } \\
\text { Assessment of Platform Capitalism and Platform } \\
\text { Cooperativism and their Effects on Workers' } \\
\text { Satisfaction) }\end{array}$ & Conference Paper & NA & $\begin{array}{l}\text { Platform Cooperativism, } \\
\text { Sustainable Development Goals }\end{array}$ \\
\hline (Stocker and Takara, 2019) & $\begin{array}{l}\text { Evaluating the Potential of Cooperative } \\
\text { Ridesourcing: A Case Study of Arcade City in Austin, } \\
\text { Texas }\end{array}$ & Report & NA & Platform Cooperatives \\
\hline (Theurl and Meyer, 2019) & Cooperatives in the Age of Sharing & Book Chapter & NA & Cooperatives, Sharing Economy \\
\hline (Tortora et al., 2019) & $\begin{array}{l}\text { Using Big Data to co-design a sustainable tourist } \\
\text { experience. Some highlights by means of a practical } \\
\text { example }\end{array}$ & Conference Paper & NA & Sustainability \\
\hline (Foramitti, Varvarousis and Kallis, 2020) & $\begin{array}{l}\text { Transition within a transition: how cooperative } \\
\text { platforms want } \\
\text { to change the sharing economy }\end{array}$ & Journal Article & Sustainability Science & $\begin{array}{l}\text { Platform Cooperativism, } \\
\text { Sustainability }\end{array}$ \\
\hline (Grayer, 2020) & $\begin{array}{l}\text { Stocksy United: A case study of co-operation in the } \\
\text { cultural industries }\end{array}$ & Thesis & NA & Platform Cooperatives \\
\hline
\end{tabular}

